\title{
グルタチオンのメラニン合成阻害機構
}

松木光雄, 渡部俊彦, ${ }^{*}$ 小笠原綾子, 三上 健, 松本達二

\section{Inhibitory Mechanism of Melanin Synthesis by Glutathione}

\author{
Mitsuo Matsuki, Toshihiko Watanabe,* Ayako Ogasawara, \\ Takeshi Mikami, and Tatsuji MATSUMOTO \\ Department of Microbiology, Tohoku Pharmaceutical University, \\ 4-4-1 Komatsushima, Aoba-ku, Sendai 981-8558, Japan
}

(Received January 11, 2008; Accepted May 2, 2008)

\begin{abstract}
Glutathione dose dependently inhibited melanin synthesis in the reaction of tyrosinase and L-DOPA. The inhibition of melanin synthesis was recovered by increasing the concentration of L-DOPA, but not recovered by increasing tyrosinase. Glutathione inhibited the binding between tyrosinase and L-DOPA. Although the synthesized melanin was aggregated within $1 \mathrm{~h}$, the aggregation was inhibited by the addition of glutathione. These results indicate that glutathione inhibits the synthesis and agglutination of melanin by interrupting the function of L-DOPA.
\end{abstract}

Key words_-glutathione; melanin; tyrosinase; 3,4-dihydroxy-L-phenylalanine

\section{緒言}

グルタチオンは, グルタミン酸, システイン, グ リシンからなるアミノ酸の一種で人間を含む動植物 や微生物の組織内に含まれている物質である.グル 夕チオンは，生体内で有害物質の解毒, 1) 老化防 止，過酸化物の生成抑制2)などを行っていることが 知られており，現在多くのサプリメントや基礎化粧 品の成分として取り入れられている.

メラニンは，紫外線から皮膚を守る防御因子とし て重要な役割を示す一方，しみ，そばかす，黒ずみ の原因となることが知られている．生体内でのメラ ニンの生成は，血中から供給されたチロシンがチロ シナーゼによって酸化されることから始まる．チロ シンは酸化されL-DOPA となり，さらにDOPA キ ノンへと代謝される，チロシナーゼはこの 2 つの反 応を触媒する酵素であり，この代謝はメラニン生成 における律速反応として働く。DOPA キノンはそ の後, 自動酸化によりメラニンとなる. ${ }^{3)}$ グルタチ オンがメラニン合成を阻害することは知られている が, ${ }^{4)}$ そのメニズムについては明らかにされてい ない，われわれは，グルタチオンのメラニン合成阻

東北薬科大学微生物学教室

e-mail: twatanabe@ tohoku-pharm.ac.jp
害メカニズムについて解析を行つたので報告する.

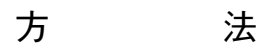

1. メラニン合成反応 リン酸緩衝液 $(8.0 \mathrm{~g} / 1$ $\mathrm{NaCl}, 0.2 \mathrm{~g} / 1 \mathrm{KCl}, 2.9 \mathrm{~g} / 1 \mathrm{Na}_{2} \mathrm{HPO}_{4} \cdot 12 \mathrm{H}_{2} \mathrm{O}, 0.2 \mathrm{~g} / \mathrm{l}$ $\mathrm{KH}_{2} \mathrm{PO}_{4}, \mathrm{pH}$ 7.2) を用いて各種試薬を溶解し, LDOPA (SIGMA-ALDRICH, 5,4-Dihydroxy-L-phenylalanine）及びチロシナーゼ（SIGMA-ALDRICH， 5370 units $/ \mathrm{mg}$ ）溶液を調整した。L-DOPA 溶液

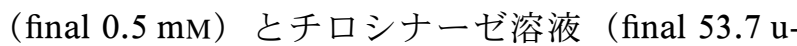
$\mathrm{nits} / \mathrm{ml})$ を，96 穴プラスチックプレート（Nunclon Delta Surface, Nunc) 内で混和後, $37^{\circ} \mathrm{C}$ で 30 分間静置した。 反応終了後, ImmnnoMini NJ-2300 （Inter Med, USA）を用いて OD490 nm 值を測定 し，これをメラニン生成量とした.

2. グルタチオンによるメラニン合成阻害効果 グルタチオン（還元型. Nacalai tesque）は，リ ン酸緩衝液に溶解し実験に使用した。グルタチオン 溶液の段階希䣋液を, L-DOPA 溶液 (final $0.5 \mathrm{mM}$ ) とチロシナーゼ溶液（final 53.7 unit $/ \mathrm{ml}$ ) の混液に 加え, 前述と同様の方法でメラニン生成量を測定し た.

グルタチオンによるメラニン合成阻害に対する L-DOPA の関与を検討するために，グルタチオン 


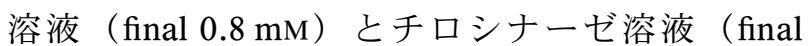
$53.7 \mathrm{unit} / \mathrm{ml})$ の混液に, 濃度の異なる L-DOPA 溶 液を加えかく拌後, 前述と同様の方法でメラニン生 成量を測定した。

また，グルタチオンによるメラニン合成阻害に対 するチロシナーゼの関与を検討するために，グル夕

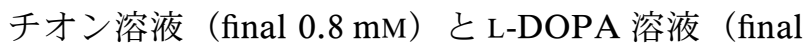
$0.5 \mathrm{mM}$ ）の混液に，濃度の異なるチロシナーゼ溶 液を加え，前述と同様の方法を用いてメラニン生成 量を測定した。

\section{3. グルタチオンによるチロシナーゼ-L-DOPA} 結合阻害グルタチオンの, チロシナーゼと LDOPA に対する結合阻害効果を，水晶発振子マイ クロバランス $(\mathrm{QCM})$ 生体分子間相互作用解析装 置 Affinix Q（Initium）を用いて検討した。すなわ ち，チロシナーゼ溶液 $(0.1 \mathrm{mg} / \mathrm{ml}) 2 \mu \mathrm{l}$ をセンサー チップ表面に固定化し，このセンサーチップを Affinex $\mathrm{Q}$ 本体に取り付けたのち, $10 \mathrm{ml}$ のリン酸 緩衝液中で周波数が安定するまで放置した。セン サーチップの周波数が安定したのち，「0.5 mM LDOPA $10 \mu \mathrm{l} 」$ 又は $「 0.5 \mathrm{~mm}$ L-DOPA $10 \mu \mathrm{l}$ 及び $0.3 \mathrm{mM}$ グルタチオン $10 \mu \mathrm{l} 」$ をン酸緩衝液中に滴 下し，センサーチップに固定化されたチロシナーゼ との反応性を, 周波数の変化から測定した.

4. グルタチオンによるメラニン凝集阻害効果 L-DOPA 溶液（final $0.5 \mathrm{mM}$ ) とチロシナーゼ溶 液（final 53.7 units/ml）をエッペンチューブ内で 混和し， $37^{\circ} \mathrm{C}$ で 30 分間静置した。 その後，グル夕

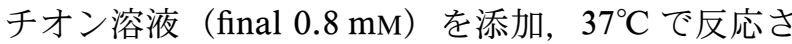
せ， 30 分毎に，この反応液の遠心上清中を回収し た。上清中の OD490 nm 值を測定し, OD490 nm 值の減少から，メラニン凝集物の生成量を算出した。

\section{5. 統計処理 実験結果は, Student's $t$-検定に} よる統計処理を行った.

\section{結果}

\section{1. グルタチオンによるメラニン合成阻害効果}

チロシナーゼと L-DOPA を混合したメラニン合 成反応液に，グルタチオンを加え，メラニン合成に 及ぼす影響を検討した。その結果，グルタチオン添 加濃度依存的にメラニン合成量が減少し，グルタチ オン最終濃度が $0.8 \mathrm{~mm}$ 以上では，メラニン合成が 完全に抑制された（Fig. 1)。この結果から，グル

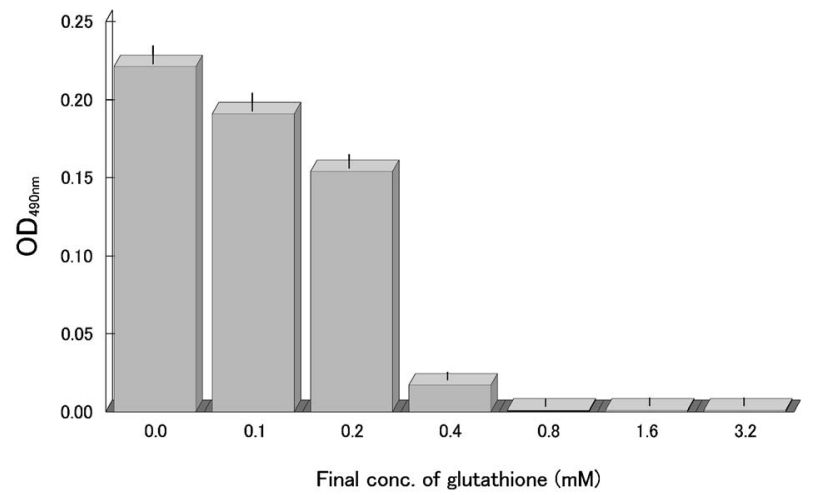

Fig. 1. Effect of Glutathione on Melanin Synthesis Glutathione was mixed with tyrosinase (final 53.7 units $/ \mathrm{ml}$ ) and L-DOPA (final $0.8 \mathrm{~mm}$ ), and incubated at $37^{\circ} \mathrm{C}$ for $30 \mathrm{~min}$. After incubation, the amount of melanin was measured as described in Materials and Methods. These results were shown as mean \pm S.E. $(n=4)$.

タチオンには，メラニン合成を阻害する効果のある ことが明らかになった。

2. グルタチオンによるメラニン合成阻害機構の 解析グルタチオンのメラニン合成阻害効果に, グルタチオンによる L-DOPA の不活性化が関与し ているか検討を行った. グルタチオン（最終濃度 $0.8 \mathrm{mM}$ ）を含むメラニン合成反応液に L-DOPA を 過剰に添加し，グルタチオンによるメラニン合成阻 害が回復するか否かを検討したところ，グルタチオ ンを含まない反応系では，メラニンの合成が認めら れたが (Fig. 2, Positive control), グルタチオン添 加群では，メラニン合成が抑制された（Fig. 2, LDOPA 最終濃度 $0.8 \mathrm{mM}$ )。 。かし，この抑制状態 は，反応液中の L-DOPA 濃度を増加させることで 回復し，L-DOPA の最終濃度が $3.2 \mathrm{mM}$ 以上で, メ ラニン生成能が完全に回復した。また，グルタチオ ンによるメラニン合成阻害がチロシナーゼの過剩添 加でも回復できるか否かについて検討を行ったが, 反応液中のチロシナーゼ濃度を通常の反応濃度（final 53.7 units $/ \mathrm{ml}$ ) の 10 倍量 (final 537.0 units $/ \mathrm{ml}$ ) に増加させても, グルタチオンによるメラニン合成 抑制状態は回復しなかった (data not shown).

さらに，メラニンと L-DOPA の結合に及ぼすグ ルタチオンの影響を Affinix Q を用いて検討したと ころ，チロシナーゼを固定化させたセンサーチップ に対し，グルタチオン非存在下では， $1.61 \pm 0.25 \mathrm{ng}$ の L-DOPA が結合したが, グルタチオン存在下で は，チロシナーゼ固定化センサーチップに対する 


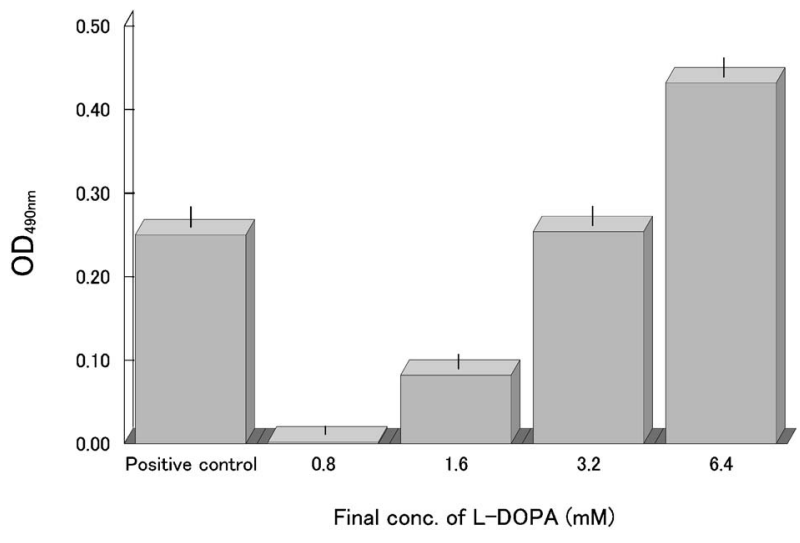

Fig. 2. Effect of L-DOPA on Inhibition of Melanin Synthesis by Glutathione

L-DOPA was mixed with glutathione (final $0.8 \mathrm{~mm}$ ) and tyrosinase (final 53.7 units $/ \mathrm{ml}$ ), and incubated at $37^{\circ} \mathrm{C}$ for $30 \mathrm{~min}$. After incubation, the amount of melanin was measured as described in Materials and Methods. These results were shown as mean \pm S.E. $(n=4)$. Positive control: The melanin synthesis by the reaction of tyrosinase (final 53.7 units $/ \mathrm{ml}$ ) and L-DOPA (final $0.8 \mathrm{~mm}$ ) without gluthatione.

L-DOPA 付着量は， $0.10 \pm 0.08 \mathrm{ng}$ で，チロシナー ゼへの L-DOPA 親和性が有意に減少していた（ $p<$ $0.001, n=3)$.

\section{3. グルタチオンによるメラニン凝集阻害効果}

本実験で行ったメラニン合成反応では，反応開始 直後から上清中の OD $490 \mathrm{~nm}$ 值は上昇し，反応開 始 30 分後で，その値はピークに達するが，その 後, 反応生成物であるメラニンが凝集・沈降するた め，上清中の OD490 nm 值は，徐々に低下する (data not shown)，反応生成物の凝集・沈降と上清 中の OD490 nm 值の低下は相関することから，遠 心上清中の OD490 $\mathrm{nm}$ 值を測定することで，メラ ニン凝集物の生成速度を測定した。メラニン合成反 応開始 30 分後にグルタチオンを添加し，添加後か ら経時的に遠心上清中の OD490 nm 值を測定した ところ，グルタチオン未添加群では，遠心上清中の OD490 nm 值は経時的に減少していたが，グルタチ オン添加群では，遠心上清中の OD490 nm 值の減 少は認められなかった（Fig. 3)。この結果から， グルタチオン添加群では，メラニン凝集物の生成が 抑制されていることが明らかになった。

\section{考察}

メラニンは，皮膚を構成する細胞内で形成される 色素であり，黒褐色のユーメラニン(真性メラニン) と，橙赤色のフェオメラニン（亜メラニン）の 2 種

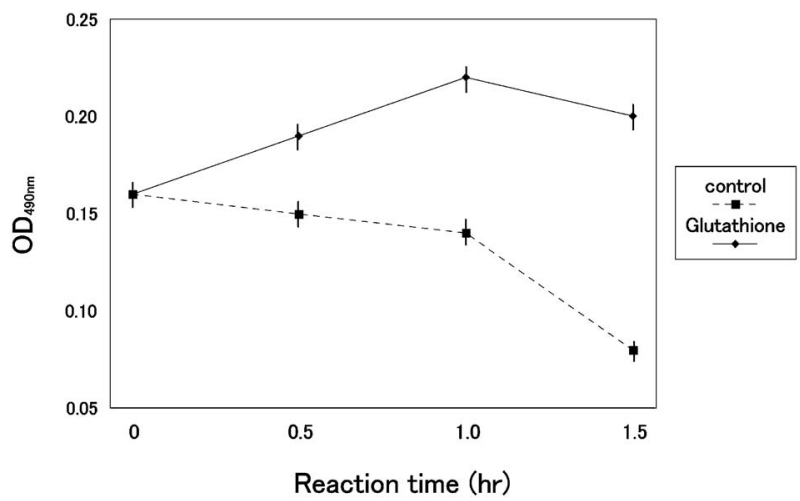

Fig. 3. Effect of Glutathione on Melanin Aggregation

L-DOPA (final $0.5 \mathrm{~mm}$ ) and tyrosinase (final 53.7 units $/ \mathrm{ml}$ ) were mixed and reacted at $37^{\circ} \mathrm{C}$ for $30 \mathrm{~min}$. Then, glutathione (final $0.8 \mathrm{~mm}$ ) was added to the mixture, and reacted at $37^{\circ} \mathrm{C}$ for the indicated time. After reaction, the supernatant was collected by centrifugation. The amount of melanin in the supernatant was measured as described in Materials and Methods. These results were shown as mean \pm S.E. $(n=4)$.

類があり，皮膚の表皮最下層の基底層や毛髪の毛母 などにあるメラノサイト(色素細胞)で生成される。

メラニンは本来，紫外線による障害から皮膚を守る 役割をしているが，多量の紫外線を浴びるとメラニ ンが過剰産生され，同時にメラノサイトの数も増加 する．高齢化などによる新陳代謝の低下で表皮のメ ラニン排出能力が低下すると，メラニンが皮膚に沈 着し，しみ，そばかすを発生すると考えられている.

現在メラニン合成阻害作用を持つものとして，い くつかのモノテルペノイドやグルコシド, ${ }^{5,6}$ ア アルブ チン7などが知られており, グルタチオンもメラニ ン合成阻害効果のある物質の 1 つである.

生体内におけるグルタチオンの生理活性は，グル タチオン抱合として知られる解毒機構や抗酸化物質 としての作用などが知られているが，グルタチオン がメラニン合成阻害を引き起こすメカニズムについ ては，明らかにされていない。本研究では，グル夕 チオンがメラニン合成を阻害するメカニズムについ て解析を行った。

メラニンは L-DOPA とチロシナーゼとの反応に よって試験管内で合成することが可能で，メラニン 合成反応が進行すると OD490 $\mathrm{nm}$ の值が上昇する ことが知られている. $\left.{ }^{8}\right)$ メラニン合成反応液にグル タチオンを加え, OD490 nm の変化を測定したとこ ろ，グルタチオン未添加群では，OD490 nm 值が上 昇することから，メラニン合成の進行が示唆された (Fig. 1)。一方，グルタチオン添加群では，OD490 
$\mathrm{nm}$ 值が，グルタチオン濃度依存的に抑制されてお り，グルタチオンがメラニン合成反応を抑制してい る事が明らかになった。ささらに，グルタチオンによ るメラニン合成阻害メカニズムを解析する目的で, グルタチオンによるメラニン合成阻害効果と反応液 中の L-DOPA 濃度との関係について検討を行つ た。その結果，Fig. 2 に示したように，グルタチオ ンによるメラニン合成阻害効果は，反応液中の LDOPA 濃度を上昇させることで阻害され，メラニ ン合成の回復が認められた。また，グルタチオンに よるメラニン合成阻害が，反応液中のチロシナーゼ 濃度を上昇させることで回復できるか否かの検討を 行ったが，メラニン合成反応液に含まれるチロシ ナーゼ濃度（53.7 units $/ \mathrm{ml）を} 10$ 倍増加させても, グルタチオンによるメラニン合成阻害状態は回復で きなかった。これらの結果から，グルタチオンは, メラニン合成反応液中の L-DOPA に作用し， LDOPA とチロシナーゼとの反応を阻害しているこ とが推察された。そこで，L-DOPA とチロシナー ゼの結合性に及ぼすグルタチオンの影響を Affinix $\mathrm{Q}$ を用いて解析した。その結果，L-DOPA とグル タチオンの結合が，グルタチオンの存在下では 90 \%以上阻害されることが明らかとなり，酵素と基質 の親和性の低下がメラニン合成阻害の要因であるこ とが示唆された。

L-DOPA とチロシナーゼの反応では，ドーパキ ノンが生成され，これが酸化・重合することにより メラニンが生成される。本実験で使用したメラニン 合成反応でも，L-DOPA とチロシナーゼを混和 後，およそ 30 分後に反応液の OD490 nm 值はピー クに達し，その後，黒色のメラニン凝集物が形成さ れた (data not shown)。メラニン凝集物は，色素 沈着によるしみ，そばかすの原因になることが予想 され，メラニン凝集を阻害することは，メラニン生 成阻害と同様に，しみ，そばかすの発生を抑制する 重要な作用と考えられる。そこで，グルタチオンの メラニン凝集阻害効果についても検討を行つた。 LDOPA とチロシナーゼによるメラニン合成反応の 開始し，メラニン分子の重合が始まる段階（反応開 始 30 分後）に，グルタチオンを添加し，メラニン 凝集物の生成状態を測定した。その結果，グル夕チ オン非存在下では, 反応液を遠心して得られる上清 中の OD490 nm 值が経時的に減少しており，反応
液中でメラニン凝集物が生成されていることが明ら かになった（Fig. 3）。一方，グル夕チオンを添加 した反応液の遠心上清では，OD490 nm 值の減少は 認められず，メラニン凝集物の生成が，グルタチオ ンによって阻害されていることが明らかになった。

L-システインやグルタチオンなどの含硫化合物 は，チロシンやL-DOPA がチロシナーゼを介して 生成される DOPA キノンに化学的に反応すること が知られており, 9) グルタチオンが DOPA キノンに 結合することによって，メラニンの生成を阻害して いる可能性が示唆されるが，本研究では，その詳細 を明らかにすることはできなかった。

グルタチオンは，食品中から摂取する以外に，細 胞内でも生合成される成分であるが，その体内生産 量は加齢に伴い低下する. ${ }^{10)}$ 高齢者では，しみ，そ ばかすの発生部位が増加する傾向があるが，その原 因の 1 つは，グルタチオン産生能の低下が関係して いることが推察された。近年，人間の平均寿命が長 くなり，若々しい容姿を保つことも健康的な生活を 送る上で重要な項目となってきている。これまでは 病気を治す医薬品の開発を目的とした研究が中心に 行われてきたが, グルタチオン等のアンチエージン グに有効と思われる因子についても，精神衛生面の 健康増進を促す薬品として，今後検討されるべきで あると考える。

\section{REFERENCES}

1) Fukui S., Uematsu K., Suzuki K., Hirayama A., Ouma M., KANGAERU EISEIKAGAKU, Hirokawa Shoten Co., 2002, pp. 367414.

2) Benathan M., Arch. Dermatol. Res., 289, 341346 (1997)

3) Shimizu H., ATARASHI HIHUKAGAKU, Nakayama Shoten Co., 2005, pp. 9-11.

4) Qiu L., Zhang M., Sturm R. A., Gardiner B., Tonks I., Kay G., Parsons P. G. J. Invest. Dermatol., 114, 21-27 (2000).

5) Kasemura K., Nomura M., Tada T., Fujihara Y., Shimomura K., J. Oleo Sci., 51, 637-642 (2002)

6) Motoki Y., Fujita S., Fujihara Y., Okada O., Nomura M., J. Oleo Sci., 52, 495-498 (2003).

7) Maeda K., Fukuda M., J. Pharmacol. Exp. Ther., 276, 765-769 (1996). 
8) Sato K., Takahashi H., Iraha R., Toriyama M., Biol. Pharm. Bull., 31, 33-37 (2008).

9) Naito K., Hatani T., Okada T., Tehara T., Biochem. Biophys. Res. Commun., 343, 15-20
(2006) .

10) Toroser D., Sohal R. S., Biochem. J., 405, 583-589 (2007). 